\title{
Direct Electron Transfer of Ferredoxins at an Indium Oxide Electrode in the Presence of Poly-L-lysine
}

\author{
Isao TANIGUCHI*, Kuniaki HAYASHI, Masato TOMINAGA, \\ Ryo MURAGUCHI and Ayuri HIROSE
}

Received February 25, 1993 ; Accepted March 19, 1993

\section{INTRODUCTION}

Recently, electrochemistry of proteins has been extensively studied, because some small proteins have become electroactive at various functional electrodes 1-2). Ferredoxin is an important electron transfer protein in a photosynthetic process, having a non-heme iron sulfur cluster as a redox center and is a nagatively charged acid protein $(\mathrm{pI}=\mathrm{ca} .<4)$. Electrochemical studies of both plant [2Fe-2S] and bacterial [4Fe-4S] ferredoxins have been carried out at methylviologen modified Au minigrid electrode ${ }^{3}$ ), and at $\mathrm{Hg}$ and graphite electrodes in the presence of poly cations ${ }^{4}$, such as $\mathrm{Cr}\left(\mathrm{NH}_{3}\right) 6^{3+}$ and neomycin. Poly-L-lysine was also reported to be

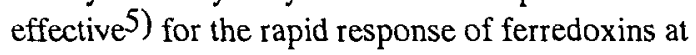
an $\mathrm{Hg}$ electrode. However, although ferredoxin is rather small protein in size (molecular weight of ca. 11,000), reported examples of rapid electron transfer at an electrode have still been limited, especially for plant ferredoxins.

In the present study, clear voltammmetric responses of spinach and maize ferredoxins have been observed at an $\mathrm{In}_{2} \mathrm{O}_{3}$ electrode in the presence of a small amount of cationic poly peptides, such as poly-L-lysine and poly-Larginine, where the formal heterogeneous electron transfer rate constant, $\mathrm{k}^{\mathrm{O}^{\prime}}$, was estimated to be $>3$ $x 10^{-3} \mathrm{~cm} \mathrm{~s}^{-1}$, as one of the best responses so far reported.

Department of Applied Chemistry,

Faculty of Engineering, Kumamoto University, 2-39-1, Kurokami, Kumamoto 860

Key words: Ferredoxin, Poly-L-lysine, Indium Oxide, Direct Electron Transfer, Modified Electrode

\section{EXPERIMENTAL}

Spinach ferredoxin was extracted from spinach leaves, and purified chromatographically on DEAE cellulose and finally on Sephadex G75 columns at $4{ }^{\circ} \mathrm{C}$. The purity of ferredoxin used was monitored by the ratio of absorbances at 424 and $277 \mathrm{~nm}, A_{424} / A_{277}$, to be $>0.5$. The concentration of spinach ferredoxin was determined spectroscopically using the molar extinction coefficient $\left.(\varepsilon=9,680)^{6}\right)$ at $420 \mathrm{~nm}$. All other reagents were of analytical grade and used as received.

Cyclic voltammograms were obtained at functional electrodes using a Toho-Giken $2020 / 2130$ potentiostat with a function generator in tris- $\mathrm{HCl}$ or Britton \& Robinson buffer solutions containing $0.33 \mathrm{M} \mathrm{NaCl}$ at various pHs. Other experimental details are similar to those described elsewhere ${ }^{2)}$.

\section{RESULTS AND DISCUSSION}

Ferredoxin gave no electrochemical response in the buffer solutions used at $\mathrm{In}_{2} \mathrm{O}_{3}$ and other promoter modified electrodes, on which rapid electron transfer of cytochrome c can take place. When divalent metal ions, such as $\mathrm{Mg}^{2+}, \mathrm{Ba}^{2+}$ and $\mathrm{Ca}^{2+}$, were added at a concentration of ca. $0.2 \mathrm{M}$, not fully-reversible but well-developed voltammetric response of spinach ferredoxin appeared at $\mathrm{In}_{2} \mathrm{O}_{3}$ and 6-mercaputopurine modified Au electrodes. Interestingly, addition of small amounts of positively charged poly peptides, such as poly-L-lysine and poly-Larginine, enhanced the ferredoxin electrochemistry to give well-defined diffusion-controlled redox 
waves. Negatively charged poly-L-glutamic acid and neutral poly-L-tyrosine (either leucine or histidine) showed no positive effect on ferredoxin electrochemistry. Addition of poly-L-lysine (e.g., ca. $5 \mu \mathrm{M}$ for a polymer of the mean molar mass of $3,600 \mathrm{~g}$ from Sigma) gave the best results at an $\mathrm{In}_{2} \mathrm{O}_{3}$ electrode.

Figure 1 shows a typical voltammogram of spinach ferredoxin together with simulated data. For purified spinach ferredoxin, the $E^{\circ}, D$, and $k^{\mathrm{O}^{\prime}}$ values of $-0.60 \mathrm{~V}$ (vs. $\mathrm{Ag} / \mathrm{AgCl} / \mathrm{sat} . \mathrm{KCl}$ ), $1.0 \times 10^{-6} \mathrm{~cm}^{-2} \mathrm{~s}^{-1}$, and $3.3 \times 10^{-3} \mathrm{~cm} \mathrm{~s}^{-1}$, respectively, were obtained in a $50 \mathrm{mM}$ tris- $\mathrm{HCl}$ buffer solution containing $0.33 \mathrm{M} \mathrm{NaCl}$ ( $\mathrm{pH}=7.5$ ) at $10^{\circ} \mathrm{C}$, from the voltammograms obtained after subtraction of the background current. The reversible reduction and reoxidation were confirmed by spectral changes. Also, no significant difference in voltammograms of ferredoxin was seen in the $\mathrm{pH} 6$ to 9 region, where ferredoxin is stable in structure.

A poly-L-lysine modified pyrolytic graphite electrode was also prepared through the peptide linkage between amino groups of poly-L-lysine and carboxyl groups on the graphite surface; a well-defined voltammograms of ferredoxin similar to that shown in Fig. 1 was again observed.

These electrodes were also effective for maize ferredoxins from both photosynthetic and nonphotosynthetic organs.

Ferredoxin acts as an electron-donating mediator for various enzyme reactions: For example, in the presence of ferredoxin-NADP+ ${ }^{+}$-reductase (FNR, E.C. $=1.18 .1 .2$, $\mathrm{NADPH}$ was monitored spectroscopically to be effectively produced in the current efficiency of near $100 \%$ from NADP+ through the reduction of ferredoxin at the electrode. By further conjugation with other enzyme reactions, where NADPH is a co-factor, various bioorganic reactions are easily designed.

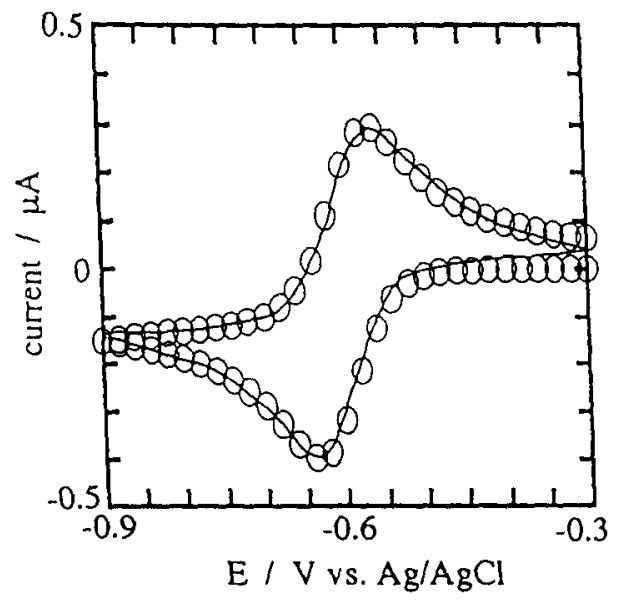

Fig. 1 Cyclic voltammograms of ca. $60 \mu \mathrm{M}$ spinach ferredoxin at an $\mathrm{In}_{2} \mathrm{O}_{3}$ electrode in the presence of $5 \mu \mathrm{M}$ poly-L-lysine (M.W. 3600) in a $50 \mathrm{mM}$ tris- $\mathrm{HCl}$ buffer solution containing $0.33 \mathrm{M} \mathrm{NaCl}(\mathrm{pH} 7.5)$ at a scan rate of $20 \mathrm{mV} \mathrm{s}^{-1}$ with simulated data shown by circles (see the text for the data used for simulation). Electrode area: $0.175 \mathrm{~cm}^{2}$.

The partial financial support of this work by a Grant-in-Aid for Scientific Research from the Ministry of Education, Science and Culture, Japan and from KAWASAKI STEEL 21st Century Foundation is gratefully acknowledged. The authors are indebted to Prof. S. Hase of Osaka University for the gift of maize ferredoxins.

\section{REFERENCES}

1) F.A. Armstrong, H.A.O. Hill and N.J. Walton, Acc. Chem. Res., 21, 407 (1988).

2) I. Taniguchi, K. Watanabe, M. Tominaga and F.M. Hawkridge, J. Electroanal. Chem., 333, 331 (1992).

3) H.L. Landrum, R.T. Salmon and F.M. Hawkridge, J. Am. Chem. Soc., 99, 3154 (1977).

4) F.A. Armstrong, H.A.O. Hill, B.N. Oliver and N.J. Walton, J. Am. Chem. Soc., 106, 921 (1984); L.H. Guo, H.A.O. Hill, G.A. Lawrance, G.S. Sanghera and D.J. Hopper, J. Electroanal. Chem., 266, 379 (1989).

5) J. Haladjian, P. Bianco and L. Asso, Electrochim. Acta, 31, 1513 (1986).

6) K. Tagawa and D.1. Arnon, Biochim. Biophys. Acta, 153, 602 (1968). 